\title{
IMPACT OF INTELLECTUAL CAPITAL ON FINANCIAL PERFORMANCE OF THE INDIAN SOFTWARE SECTOR
}

\author{
Deepika Bansal ${ }^{1}$ and Shveta Singh ${ }^{2}$ \\ ${ }^{1}$ Research Scholar, Guru Jambheshwar University of Science \& Technology, India \\ E-mail: deepikaaggarwal2701@gmail.com \\ ${ }^{2}$ Faculty of Management, Guru Jambheshwar University of Science \& Technology, India \\ E-mail: shvetachahal@gmail.com
}

\begin{abstract}
The purpose of the study was to analyse and examine the effect of intellectual capital on profitability and productivity of the Indian software sector. An empirical investigation was done on 71 software companies. Data for the study was collected from the CMIE prowess database for the period of five years from 2013 to 2018. The Value Added Intellectual Coefficient (VAIC) Model was used for the measurement of intellectual capital (IC) and its components. The Pearson and Panel Regression Model was used for the analysis of data. The findings show that, varying relationships exist between intellectual capital components and financial performance measures such as profitability and productivity. Findings of the study also suggest that VAIC, positively and significantly explains profitability of the companies but not productivity. Intellectual capital is an interesting area for all the parties like managers, shareholders, government, institutional investors, policy makers etc. This study increases the knowledge of all parties about the impact of intellectual capital on performance of concerned companies. The results of the study can be utilised for the enhancement of productivity and profitability of companies by a proper management of intellectual capital.
\end{abstract}

Keywords: intellectual capital, software sector, profitability, productivity, financial performance

\section{ARTICLE INFO}

\section{Article History:}

Received: 31 October 2019

Accepted: 3 February 2020

Published: 30 April 2020 


\section{INTRODUCTION}

\section{Intellectual Capital}

The development of the "new economy" which is information and knowledge intensive, has generated attention and interest towards intellectual capital (Petty \& Guthrie, 2000). Since intellectual capital is that area which is capturing the interest of many scholars and practitioners, the significance of intellectual capital in determining the corporate value is enhanced (Tan et al., 2007). During the last two decades, globalisation and technical advancement are two worthwhile factors that improved the performance of firms. Under these conditions, intellectual capital and intangible resources are crucial factor for success (Alipour, 2012). Furthermore, due to the inception of intellectual capital resources modern organizations can make their strategies to face the competition prevailing in the market while not being entirely dependent at the diminishing level of physical resources which are scarce in nature (Kehelwalatenna, 2016).

Intellectual capital is generally defined as knowledge related intangible assets belonging to an organisation (Kehelwalatenna \& Premarantne, 2014). Intangible assets refer to those assets which are recognised by accounting standards as assets and mentioned in the balance sheet. Intellectual capital are intangible assets such as software, patents, infrastructure and databases which can be mentioned in traditional financial accounts (Ting \& Lean, 2009). The term intellectual capital was firstly used by economist, John Kenneth. Intellectual capital is a sum up of human capital and structure capital that is package of customers, processes, brands and databases (Edvinsson \& Malone, 1997). Yongvanich and Guthrie (2005) expressed intellectual capital as a combination of three variables:

\section{External capital \\ 2. Internal capital and \\ 3. Human capital}

Measurement of intellectual capital is important because a firm has information about what it owns but it does not measure the processes which helps to reach that stage. Intellectual capital is a wider concept, which generally has three categories such as human capital, structural capital and relational capital. 
Human capital (HC) consists of implicit and explicit knowledge of employees. It also includes capabilities, competency and skills of employees, which they use to perform firms' activities (Komnenic \& Pokrajcic, 2012). $\mathrm{HC}$ is the heart of intellectual capital, a unique feature of this capital is that it does not remain in the firm when employees leave (Chen et al., 2005). Innovation in the form of new products and services is generated by human capital.

Structural capital (SC) refers to that knowledge which remains in the firm, either employees leave the firm or stay in the firm. It includes databases, culture, system, procedures of the firm. This capital also known as organisational capital (Jashapara, 2004; Petty \& Guthrie, 2000). Bontis (1998) has provided that intellectual capital does not reach to its fullest capability if the organisation has poor procedural system for tracking its actions. According to Bontis (1998) structural capital is that mechanism in firms which helps employees to optimize intellectual and increase firm performance. In the words of Ahangar (2011) SC is a supportive structure for $\mathrm{HC}$, such as organizational processes, data patents.

Relational capital/capital employed is defined as a firm's relationship with its investors, customers, partners in research and development. Kaplan and Norton (1996) had identified that in the present scenario, the focus of the service profit chain is to build a relationship between customer satisfaction, employee satisfaction, customer commitment and financial performance of the firms. Customer loyalty and commitment can be projected by the measurement of employees' loyalty and commitment (Horibe, 1999). According to Ghosh and Wu (2007) a firm's franchise, market share, defection rates all are elements of relational capital. Kohli and Jaworski (1990) describe it as a market intelligence generated by an organization, considering current and future needs of customers. IT (Information Technology) sector is the fastest growing knowledge intensive sector which uses more of intellectual capital than physical assets (Kaur, 2014). In the present scenario India's IT industry's main focus is on digital opportunities. This segment will be the major segment in the next few years, currently growing at 30\% annually (India Brand Equity Foundation, 2018). Indian IT and BPM (Business Process Management) industry are expected to grow to US $\$ 350$ billion by 2025 (India Brand Equity Foundation, 2018). The IT sector contributed 9.3\% in India's GDP in FY 2015-2016 (Singh 
$\&$ Kaur, 2017). One of the information technology sectors is the Software sector. Therefore, the present study adds to the literature by analysing the association between VAIC and its components as a representative of intellectual capital and financial performance of Indian Software companies listed on the Bombay Stock Exchange (BSE). The Indian Software sector is a knowledge intensive one and the most preferred sector by research scholars for studying the role played by intellectual capital in firm performance (Mondal, 2016; Shaban \& Kavida, 2013). The large amount of knowledge and information in the form of innovation, technological advancement and skills is required to perform business activities of the Software companies which in turn builds competitive advantage for the companies. Therefore, it is required by the sector to invest large in the training and development of human beings. Innovation, knowledge and skills are the basic factors of intellectual capital, performance of which in a firm needs to be measured. The importance of the Indian Software sector can be measured by its provisions of providing efficient technology and solutions of business problems. These provisions make this sector reputed across the boundaries (Stats and Insights of the Indian IT and Software Industry, 2019). Presence of the Indian Software sector has led the emerging economies to the height of immense success. The very first company established to provide software services and products was the "Computer Usage Company, 1955". But the Software sector became successful in India with the coming of "Tata Consultancy Services" in 1960. The Indian software Industry has grown from a mere US \$ 150 million in 1991-92 to a staggering US \$ 5.7 billion in 1999-2000 (Sarangi, 2011). The contribution of the Indian Software sector in the compounded growth of the economy is 65\% annually (Ministry of Finance, 2006). More than 95 countries all over the world are getting IT services from Indian software companies. The Indian Software sector has its own brand equity in the global market. The software sector responds to serve shortage of manpower by creating a pool of efficient and technical manpower in the overseas markets (Stats and Insights of the Indian IT and Software Industry, 2019). The Indian Software sector is serving small and medium enterprises (SMEs) and large organisations by providing software products, $\mathrm{R} \& \mathrm{D}$ services and engineering services (Software Sector Analysis Report, 2019). Hence, there is a need to measure the performance of intellectual capital in the Software sector, in order to maintain the competitiveness of the sector in the domestic and global markets. 
There has been a widespread research on IC that has generated various number of methods for classification and measurement of the concept. Petrash's (1996) provided the Value Platform model that describes IC as the total of human capital, customer capital and organisational capital. Haanes and Lowendahl (1997) measured IC as a combination of relational and competence resources. The present study used the Public Model. Under this model, VAIC (value added intellectual coefficient) is calculated for the IC measurement. This model measures the role, played by both tangible and intangible assets in the creation of value for a firm. VAIC is the combination of three variables:

1. Human capital coefficient

2. Structural capital coefficient

3. Physical capital coefficient

\section{LITERATURE REVIEW, RESEARCH GAP AND DEVELOPMENT OF HYPOTHESES}

Measurement of intellectual capital has been a vital topic of interest for research scholars before 1990. Roslender et al. (2006) stated that financial statements of companies should contain information on intellectual capital along with other resources of an organisation. Moreover, a complete image of firm value and its performance can be present when all aspects of a firm are taken into consideration. Therefore, along with the correct computation of IC, information yielded should be utilized efficiently (Roos, 2003). Studies considering the impact of intellectual capital on firm performance are mentioned below:

Tan et al. (2007) investigated the effect of intellectual capital on financial performance of 150 companies listed in the Singapore Stock Exchange. Their study revealed that, firms that were actually having and utilizing their intellectual capital efficiently were having good financial performance. Kehelwalatenna (2016) studied New York listed banking firms to analyse how intellectual capital is related to productivity, profitability and revenue growth of the banks. The study found that IC has $\mathrm{N}$ inconsistent effect on all three measures of firm performance. Najibullah (2005) found that, in Bangladesh the intellectual capital components such as human, 
structural and capital employed efficiency had a positive association with a bank's market value. According to Appuhami (2007) efficient use of intellectual capital increases the investors gain on shares. The findings of the study upgraded the knowledge related to intellectual capital.

Nadeem et al. (2016) observed a strong relationship between intellectual capital efficiency and profitability of companies in terms of return on assets (ROA) and return on equity (ROE) in BRICS economies. Kehelwalatenna and Premarantne (2014) selected, banking firms listed in the New York Stock Exchange and found that intellectual capital contributed positively in increasing the performance of the banks. Maji and Goswami (2015) selected the Indian engineering and steel sector from 1999-2013. They investigated the importance of IC on the performance of these sectors, and found that human capital, as one of the variables of IC, had a positive and significant effect on the performance of these sectors.

Tseng and Goo (2005) carried out a study in Taiwan and argued that IC was found to be positively associated with profitability and market value of Taiwanese firms. Maditinos et al. (2011) conducted a study on Greek listed firms during 2006-2008 and concluded that only human capital efficiency was significantly related with performance of the firms. Wang and Chang (2005) studied the impact of IC on performance of information technology firms listed in Taiwan by using the Partial Least Square model. The study found that performance of the firms is directly impacted by innovation capital, customer capital and process capital while human capital had an indirect impact on firm's performance.

A survey was conducted in Jordan by Sharabati et al. (2010) on the pharmaceutical sector and observed that these firms were handling their intellectual capital fruitfully, which enhancing the performance of their business positively. A study carried out by Kujansivu and Lonnqvist (2005) on Finnish corporations by applying VAIC and CIV for calculating intellectual capital efficiency in adding value. The results showed that no relationship exist between value added and intellectual capital efficiency. Similar results were generated by Chan (2009); Chen et al. (2005); Mavridis (2005) and Chu et al. (2007). 


\section{Research Gap}

After reviewing existing literature, it can be concluded that most of the studies related to intellectual capital were conducted in developed economies. In a developing economy like India it is still at the infancy stage. India is a developing country and has huge potential of Human Capital Efficiency (HCE) and Structural Capital Efficiency (SCE) and therefore immense success is available in studying the performance of intellectual capital. Intellectual capital efficiency and its relation with companies' performance will be helpful to the Indian IT sector policy makers, society and academicians at large in making informed decisions.

\section{Development of Hypothesis}

As per the resource-based view of the firm, acquisition, holding and successive use of strategic assets help a firm to earn competitive advantage (Wernerfelt, 1984). The resource-based view of the firm, considers the benefits of both intangible and tangible assets, is becoming popular in the economic accounting literature following a positive relationship between firm resources and measures of performance (Riahi-Belkaoui, 2003). According to authors, intellectual capital enhances the competitive advantage of firms.

According to Sofian et al. (2006) intellectual capital is a major player in enhancing the revenue of firms and it has a countable effect on firm performance. Patton (2007) argued that a firm can increase its productivity by relying more on its intellectual capital than on its financial and physical capital. Similarly, Bontis et al. (2000) showed that use of knowledgeable and intellectual assets led firms to the path of success. On the basis of these studies, the following hypotheses were developed to investigate the relationship between intellectual capital efficiency which is measured by VAIC and two measures of financial performance:

$\mathbf{H}_{1 \mathbf{a}}$ : Intellectual capital is significantly related to profitability of Indian software companies.

$\mathbf{H}_{\mathbf{1 b}}$ : Intellectual capital is significantly related to productivity of Indian software companies. 
The Resource Dependency (RD) Theory focuses on the importance of human resources that helps a firm to maintain a long-lasting relationship with stakeholders. Taking into consideration this perspective of the RD theory, Abeysekera (2010) provided that a firm may have effective association with its external environment with the presence of effective and efficient human resources (human capital). Similarly, Williams (2000) described that proper and efficient use of human capital increases a firm's performance in each and every way. On the basis of these studies, the following hypotheses were developed to investigate the relationship between human capital efficiency and two measures of financial performance:

$\mathbf{H}_{\mathbf{2}}$ : Human capital efficiency is significantly related to profitability of Indian software companies.

$\mathbf{H}_{2 \mathbf{b}}$ : Human capital efficiency is significantly related to productivity of Indian software companies.

On the basis of the Organizational Learning (OL) Theory, Njuguna (2009) depicted that being a process, organizational learning helps a firm to acquire new knowledge that generates innovation and can be protected by unique properties such as patents and copyrights- which is also called intellectual property. Investment on $R \& D$ generates intellectual property and these intellectual properties are termed as structural capital (Stewart \& Ruckdeschel, 1998). Hence, the role played by SC in creating the value for a firm can be studied by using the OL Theory. Hudgins (2014) also found that structural capital is significantly related with performance of insurance companies which is measured by profitability and productivity. Therefore, on the basis of these studies, the following hypotheses were developed to investigate the relationship between structural capital efficiency and two measures of financial performance:

$\mathbf{H}_{3 \mathbf{a}}$ : Structural capital efficiency is significantly related to profitability of Indian software companies.

$\mathbf{H}_{3 \mathbf{b}}$ : Structural capital efficiency is significantly related to productivity of Indian software companies.

Pulic (1998) stated that intellectual capital resources cannot perform successfully without physical and financial capital resources. This is why ante public defined his VAIC model as a combination of IC and physical 
resources. Moreover, physical capital is positively and significantly related with profitability and productivity of a firm (Ting \& Lean, 2009; Vishnu \& Gupta, 2014). Hence, on the basis of these studies, the following hypotheses were developed to investigate the relationship between capital employed efficiency and two measures of financial performance:

$\mathbf{H}_{4 \mathbf{a}}$ : Capital employed efficiency is significantly related to profitability of Indian software companies.

$\mathbf{H}_{\mathbf{4 b}}$ : Capital employed efficiency is significantly related to productivity of Indian software companies.

\section{RESEARCH METHODOLOGY}

\section{Data Collection}

Secondary data was collected from the Prowess database, which is maintained by Centre for Monitoring Indian Economy (CMIE). A sample, consisting of 71 companies, from the knowledge-based, software sector was taken for the study. Sample companies were listed in the Bombay Stock Exchange (BSE). Panel data of these 71 companies were obtained for estimation from the Prowess database.

\section{Measurement of Variables}

\section{Dependent variables}

To carry out the research two variables were used as proxy to measure company's financial performance.

ROA (return on assets), which is the measurement of company profitability calculated as:

$$
\text { ROA }=\text { Operating income } / \text { Total assets }
$$

ATO (assets turnover ratio), which is the measurement of company productivity calculated as:

$$
\mathrm{ATO}=\text { Total revenue } / \text { Total assets }
$$




\section{Control variables}

DER (debt equity ratio) is the measurement of company leverage deciphered using following formula.

$$
\text { DER }=\text { Total debt } / \text { Total equity }
$$

PC (physical capacity): which measures the firm's fixed assets out of total assets.

$$
\mathrm{PC}=\text { Fixed assets / Total assets }
$$

Log (total assets): which is the proxy for firm size is:

$$
\text { Total assets }=\log (\text { total assets })
$$

\section{Independent variables}

Pulic $(1998,2000)$ developed a model the "Value Added Intellectual Coefficient" to measure intellectual capital efficiency. According to Pulic (2000), the VAIC model helps stakeholder to analyse and evaluate the value creation ability of a firm's total resources. It is considered to be best model due to its simple procedure of measurement. The model starts with the firm's ability in creation of value added (VA). Value added is computed as follows:

$$
\mathrm{VA}=\text { Output }- \text { Input }
$$

Output are all the products and services which are sold in the market for the purpose of generation of revenue. Inputs include all expenses incurred in the production of goods and service except costs incurred on manpower. Under this model manpower expenses not considered as cost; it is investment for the firm which creates value.

VA is also written as:

VA in the form of gross value added:

$$
\mathrm{VA}=\mathrm{DP}+\mathrm{I}+\mathrm{D}+\mathrm{M}+\mathrm{R}+\mathrm{T}+\mathrm{W}
$$

VA in the form of net value added:

$$
\mathrm{VA}=\mathrm{W}+\mathrm{I}+\mathrm{T}+\mathrm{NI}
$$


Where,

DP refers as depreciation expenses

I refer as interest expenses

$\mathrm{D}$ refers as dividend expenses

$\mathrm{M}$ refers as minority expenses

$\mathrm{R}$ refers as retained earnings

$\mathrm{T}$ refers as taxes

W refers as wages and salaries

NI refers as net income.

Further,

VAIC is the combination of three components:

$$
\mathrm{VAIC}=\mathrm{HCE}+\mathrm{SCE}+\mathrm{CEE}
$$

1. Human Capital Efficiency (HCE) measures how much value added is created by each unit of money, spent on manpower. Under this model, total salary and wages paid to employees is referred to as human capital. It is calculated by the ratio between value added and total salary and wages of employees.

$$
\mathrm{HCE}=\mathrm{VA} / \mathrm{HC}
$$

where,

$\mathrm{VA}=$ value added

$\mathrm{HC}=$ total salary and wages of employees

2. Structural Capital Efficiency (SCE) measures how much value is created by structural capital. It is the difference between VA and HC. On the basis of prior empirical studies, Pulic (1998) provided that $\mathrm{HC}$ and SC are inversely related to each other. Hence, the lesser the participation of $\mathrm{HC}$ in value added, the greater the contribution of SC in value added. SCE is calculated by ratio between SC and VA of the firm.

$$
\mathrm{SCE}=\mathrm{SC} / \mathrm{VA}
$$


where,

$\mathrm{VA}=$ value added

$\mathrm{SC}=$ structural capital $(\mathrm{VA}-\mathrm{HC})$

3. Capital Employed Efficiency (CEE) measures the value which is created by net worth of the company. CEE is calculated by ratio between VA and CE of the company.

$$
\mathrm{CEE}=\mathrm{VA} / \mathrm{CE}
$$

where,

$\mathrm{VA}=$ value added

$\mathrm{CE}=$ capital employed.

Despite the popularity due to its simplicity the VAIC model is not free from limitations. According to Firer and Williams (2003) this model shortened the data by excluding the firms having negative structural capital. Also, this model does not use the concept of relational capital. Andriessen (2004) has generated attention towards the limitations of VAIC regarding its basic assumptions and validity.

Independent Variables

Dependent Variables

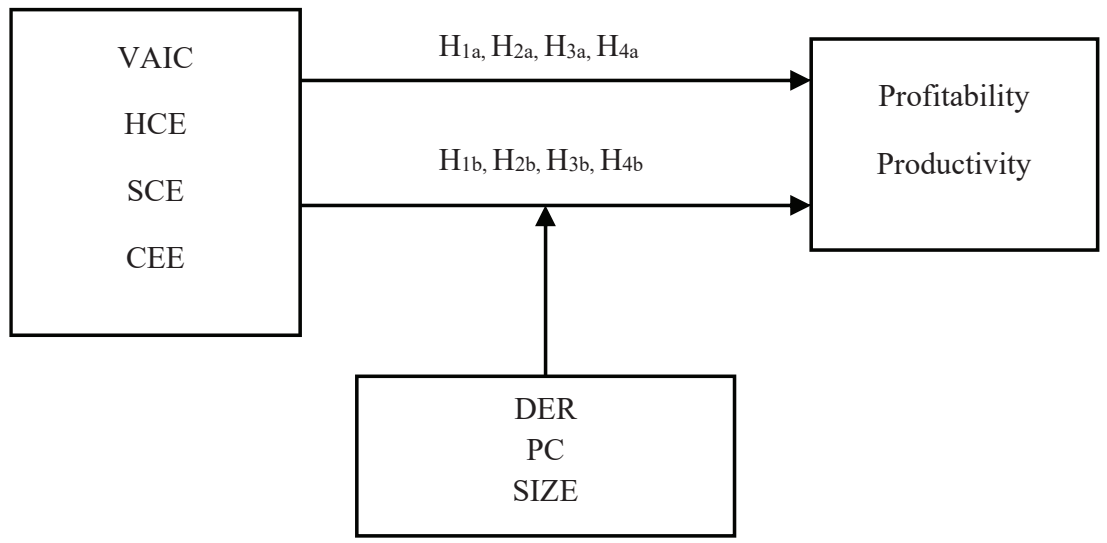

Control Variables

Figure 1: Theoretical Framework of Research 


\section{Regression Model}

Due to the panel data, the Panel Regression Model was used to see the effect of intellectual capital on performance of software companies.

Following regression equations are used to test the hypothesis:

$$
\begin{aligned}
& \mathrm{ROA}_{\text {it }}=\alpha_{i t}+\beta_{1} \mathrm{VAIC}_{\mathrm{it}}+\beta_{2} \mathrm{DER}_{\mathrm{it}}+\beta_{3} \mathrm{PC}_{\mathrm{it}}+\beta_{4} \mathrm{Size}_{\mathrm{it}}+€_{\mathrm{it}} \\
& \mathrm{ROA}_{\mathrm{it}}=\alpha_{\mathrm{it}}+\beta_{1} \mathrm{HCE}_{\mathrm{it}}+\beta_{2} \mathrm{SCE}_{\mathrm{it}}+\beta_{3} \mathrm{CEE}_{\mathrm{it}}+\beta_{4} \mathrm{DER}_{\mathrm{it}}+ \\
& \beta_{5} \mathrm{PC}_{\mathrm{it}}+\beta_{6} \mathrm{Size}_{\mathrm{it}}+€_{\mathrm{it}} \\
& \mathrm{ATO}_{\mathrm{it}}=\alpha_{\mathrm{it}}+\beta_{1} \mathrm{VAIC}_{\mathrm{it}}+\beta_{2} \mathrm{DER}_{\mathrm{it}}+\beta_{3} \mathrm{PC}_{\mathrm{it}}+\beta_{4} \mathrm{Size}_{\mathrm{it}}+€_{\mathrm{it}} \\
& \mathrm{ATO}_{\text {it }}=\alpha_{\mathrm{it}}+\beta_{1} \mathrm{HCE}_{\mathrm{it}}+\beta_{2} \mathrm{SCE}_{\mathrm{it}}+\beta_{3} \mathrm{CEE}_{\mathrm{it}}+\beta_{4} \mathrm{DER}_{\mathrm{it}}+ \\
& \beta_{5} \mathrm{PC}_{\mathrm{it}}+\beta_{6} \mathrm{Size}_{\mathrm{it}}+€_{\mathrm{it}}
\end{aligned}
$$

\section{DISCUSSION OF THE RESULTS}

Table 1 and 2 depict the descriptive statistics for all variables. Mean value of $\mathrm{HCE}, \mathrm{SCE}$ and $\mathrm{CEE}$ are 2.28, 0.37 and 0.67 percent respectively which suggests that during the study period, among all the components of intellectual capital, human capital generated more capital. 2.28 percent indicates that software companies created value of 2.28 percent for each unit of rupee spent on human resources in the companies. This result is similar with the result found by Ho and William (2003). The Mean value of ROA is 9.19 percent which indicates that IT software companies are earning a good return on total assets which includes both tangible and intangible assets. ATO has 0.66 mean value, which is not at par. 
Table 1: Descriptive Statistics of Intellectual Capital and Its Components

\begin{tabular}{ccccc} 
& VAIC & HCE & SCE & CEE \\
\hline Mean & 3.327467 & 2.282365 & 0.371133 & 0.679181 \\
Median & 2.58475 & 1.528678 & 0.34527 & 0.559719 \\
Maximum & 33.66922 & 32.21914 & 0.968963 & 3.093023 \\
Minimum & 1.007143 & 1.00361 & 0.00000 & 0.003947 \\
Std. Div. & 3.322692 & 3.215382 & 0.211983 & 0.560633 \\
Skewness & 5.968297 & 6.32628 & 0.743987 & 1.502327 \\
Kurtosis & 45.12663 & 48.5717 & 3.340697 & 6.086328 \\
Observations & 355 & 355 & 355 & 355 \\
\hline
\end{tabular}

Table 2: Descriptive Statistics of Other Variables

\begin{tabular}{cccccc}
\hline & ROA & ATO & DER & PC & SIZE \\
\hline Mean & 9.197324 & 0.667504 & 0.258338 & 0.489125 & 3.181437 \\
Median & 7.57 & 0.64716 & 0.02 & 0.476679 & 3.054192 \\
Maximum & 37.53 & 2.249833 & 31.34 & 0.997222 & 5.962724 \\
Minimum & -22.46 & 0.00000 & 0.0000 & 0.012551 & 0.863323 \\
Std. Div. & 8.628464 & 0.423189 & 1.805334 & 0.23604 & 1.102486 \\
Skewness & 0.664538 & 0.730559 & 15.0994 & 0.075149 & 0.508937 \\
Kurtosis & 3.742971 & 3.551746 & 252.0445 & 2.268529 & 2.932351 \\
Observations & 355 & 355 & 355 & 355 & 355 \\
\hline
\end{tabular}

A correlation analysis was done, to test the relationship between all variables. The results of correlation analysis is shown in Tables 3 and 4. Table 3 depicts the correlation between VAIC and other selected variables. The results in Table 3 show that a positive and significant relationship exists between IC which is represented by VAIC, ROA and ATO at the $1 \%$ level of significance. This table also shows that intellectual capital is negatively and significantly related with PC at the $1 \%$ level of significance level and has no relationship with DER. Results in the Table 3 clearly shows that use of IC increases profitability and productivity in the form of ROA and ATO. Table 4 depicts the association between intellectual capital components and 
other variables. This table indicates that human and structural capital are positively and significantly related with ROA but have no significant relation with ATO. Table 4 also reveals the relation between capital employed and other variables. The capital employed has positive and significant relation with ROA and ATO at the $1 \%$ level. Overall, results found that only capital employed (physical capital) has positive relation with a firm's financial performance.

Table 3: Correlation Probability of VAIC and Other Variables

\begin{tabular}{ccccccc} 
& VAIC & ROA & ATO & DER & PC & SIZE \\
\hline VAIC & 1.000 & & & & & \\
ROA & $0.233^{* *}$ & 1.000 & & & & \\
ATO & $0.203^{* *}$ & $0.556^{* *}$ & 1.000 & & & \\
DER & 0.033 & $-0.176^{* *}$ & -0.078 & 1.000 & & \\
PC & $-0.209^{* *}$ & $-0.386^{* *}$ & $-0.461^{* *}$ & 0.101 & 1.000 & \\
Size & $0.129^{*}$ & $0.510^{* *}$ & $0.340^{* *}$ & -0.055 & $-0.277^{* *}$ & 1.000 \\
\hline Note: * and ** Shows Significant Level At $1 \%$ and $5 \%$ Respectively & & &
\end{tabular}

Table 4: Correlation Probability of VAIC Variables and Other Variables

\begin{tabular}{lllllllll}
\hline & HCE & SCE & CEE & ROA & ATO & DER & PC & SIZE \\
\hline HCE & 1.000 & & & & & & & \\
SCE & $0.632^{* *}$ & 1.000 & & & & & & \\
CEE & $-0.140^{* *}$ & $-0.149^{* *}$ & 1.000 & & & & & \\
ROA & $0.144^{* *}$ & $0.288^{* *}$ & $0.436^{* *}$ & 1.000 & & & & \\
ATO & 0.095 & -0.092 & $0.677^{* *}$ & $0.556^{* *}$ & 1.000 & & & \\
DER & -0.012 & -0.026 & $0.269^{* *}$ & $-0.176^{* *}$ & -0.078 & 1.000 & & \\
PC & $-0.157^{* *}$ & $-0.195^{* *}$ & $-0.250^{* *}$ & $-0.386^{* *}$ & $-0.461^{* *}$ & 0.101 & 1.000 & \\
Size & 0.072 & 0.099 & $0.314^{* *}$ & $0.510^{* *}$ & $0.340^{* *}$ & -0.055 & $-0.277^{* *}$ & 1.000 \\
\hline Note: **Shows Significant Level At $1 \%$ Respectively & & & & &
\end{tabular}




\section{Results of Panel Regression Analysis}

To see the impact of intellectual capital on productivity and profitability, panel regression was applied. Since the data was of a panel nature both the Fixed Effect and Random Effect Model was used. The Hausman Specification Test (Hausman, 1978) was used to check the results of both the models. If the Hausman Specification Test showed that the results of both models are significant then the Random Effect Model was used. Table 5 depicts the regression results when ROA is the dependent variable. Table 5 shows that adjusted R2 is $71.7 \%$ which means that $71.7 \%$ change in profits of companies occurred by VAIC and rest is due to availability of other variables. The results in Table 5 also shows that the model is good enough to explain the variations in the dependent variable. The Probability value of the Hausman test is 0.0015 , which is smaller than 0.05 , which indicates that the Fixed Effect Model is more appropriate to be used. It is clearly shown in Table 5 that VAIC has a positive and significant effect on profitability of the software companies, which indicates that firm's profitability increases by increasing the use of intellectual capital. Hence, $\mathrm{H} 1 \mathrm{a}$ is accepted implying that intellectual capital is significantly related with profitability of the companies. It is concluded from the results that ROA is increased by 0.73 when there is 0.1 increase in intellectual capital. Among the control variables, debt ratio has negative and insignificant relation with company's profitability which is supported by the Pecking Order Theory of capital structure, which means that more profitable firms use less amount of debt. Size in terms of total assets was found to have a negative but significant relation with ROA. The results of the study are supported by Vishnu and Gupta (2014) and Maji and Goswami (2015). 
Table 5: Panel Regression Results When ROA is Dependent Variable

\begin{tabular}{ccc} 
& Fixed effect & Random effect \\
\hline Intercept & $23.51737^{*}$ & 0.864055 \\
VAIC & $(3.093)$ & $(0.349)$ \\
& $0.730687^{*}$ & $0.505646^{*}$ \\
DER & $(3.168)$ & $(3.193)$ \\
& -0.25338 & $-0.37855^{* *}$ \\
PC & $(-1.344)$ & $(-2.139)$ \\
SIZE & -3.58571 & $-5.52003^{*}$ \\
& $(-1.401)$ & $(-27217)$ \\
Adjusted R & $-4.6935^{* *}$ & $2.969893^{*}$ \\
F statistic & $(-2.033)$ & $(4.930)$ \\
Hausman test & 0.7177 & 0.1381 \\
\hline Note: ${ }^{* *}$ and ${ }^{* *}$ represents level of significance at 1.5 and $10 \%$ respectively. Values of t-statistics are in parenthesis.
\end{tabular}

Table 6 depicts the results of the regression analysis when ATO is the dependent variable. As the Table shows the adjusted R2 is $83.9 \%$ which indicates that the model is good enough to explain changes in the dependent variable. The Hausman Chi X2 test found that the Fixed Effect model is appropriate. From the results it is found that the estimated coefficients of VAIC is positive but insignificant. This shows that an increase in intellectual capital does not increase the productivity of the concerned companies. Hence, $\mathrm{H}_{1 \mathrm{~b}}$ is rejected, indicating that intellectual capital is significantly related to productivity of companies. The negative influence of $\mathrm{PC}$ and size on ROA demonstrate that productivity of the companies is not increased by the size and PC of the companies. Contradictory to the results of this study, Gan and Saleh (2008) and Firer and Stainbank (2003) found that IC has a negative but significant power to explain productivity of Malaysian and South African companies. 
Table 6: Panel Regression Results When ATO is Dependent Variable

\begin{tabular}{ccc} 
& Fixed effect & Random effect \\
\hline Intercept & $1.745256^{*}$ & $0.623908^{*}$ \\
VAIC & $(6.204)$ & $(4.856)$ \\
& 0.005754 & 0.008465 \\
DER & $(0.674)$ & $(1.191)$ \\
& -0.00395 & -0.00595 \\
PC & $(-0.567)$ & $(-0.8782)$ \\
& $-0.17246^{* * *}$ & $-0.27381^{*}$ \\
SIZE & $(-1.821)$ & $(-3.213)$ \\
& $-0.31795^{*}$ & 0.04743 \\
Adjusted R & $(-3.722)$ & $(1.414)$ \\
F statistic & 0.839 & 0.037 \\
Hausman test & $25.988^{*}$ & $4.466^{*}$ \\
\hline
\end{tabular}

Note: ${ }^{*},{ }^{\star *}$ and ${ }^{* \star *}$ represents level of significance at 1,5 and $10 \%$ respectively. Values of t-statistics are in parenthesis.

\section{Regression Results of VAIC Variables and Measures of Financial Performance}

Table 7 provides the regression results when ROA is the dependent variable and the VAIC components are independent variables. The results of analysis show that the independent variables HCE, SCE and CEE have $74.6 \%$ explanatory power about the change in ROA. Results of the Hausman Chi2 provides that the Fixed Effect Model is more fit to be used for analysis of ROA. The Table shows that human capital has insignificant influence on firm's profitability. This implies that human capital has no role in increasing the profit of firms. Therefore, $\mathrm{H}_{2 \mathrm{a}}$ is rejected implying that $\mathrm{HCE}$ and firm profitability are significantly related.

The results also report that the impact of SCE on ROA are positively significant at the $1 \%$ level, which implies that SC plays an important role in increasing the profitability of companies. Results of the analysis also showed that CEE has a positive and significant association with ROA. Hence, $\mathrm{H} 3 \mathrm{a}$ and $\mathrm{H} 4 \mathrm{a}$ are accepted indicating that there is a significant relationship between SCE and CEE with profitability of companies. Other control variables, leverage and PC were found to have no contribution in 
increasing the ROA of the companies. Size was found to be significantly but negatively related with company's profitability. It is clear from the results that any increase in SCE and CEE would lead to the generation of more profit for the companies and it is also concluded that among the components of VAIC, structural capital generates more profit then human and physical capital.

Table 7: Panel Regression Results When ROA is Dependent Variable

\begin{tabular}{ccc}
\hline & Fixed effect & Random effect \\
\hline Intercept & $18.20923^{* *}$ & $-4.78486^{* *}$ \\
& $(2.416)$ & $(-2.258)$ \\
HCE & -0.12656 & -0.13966 \\
SCE & $(-0.480)$ & $(-0.841)$ \\
& $15.99935^{*}$ & $13.46248^{*}$ \\
CEE & $(5.551)$ & $(5.992)$ \\
& $3.119943^{*}$ & $5.336449^{*}$ \\
DER & $(2.617)$ & $(6.726)$ \\
& -0.2095 & $-0.55412^{*}$ \\
PC & $(-1.164)$ & $(-3.342)$ \\
& -2.44451 & $-3.82744^{* *}$ \\
SIZE & $(-1.003)$ & $(-2.152)$ \\
& $-4.88149^{* *}$ & $2.41884^{*}$ \\
Adjusted R & $(-2.163)$ & $(5.048)$ \\
F statistic & 0.746 & 0.302 \\
Hausman test & $14.735^{*}$ & $26.58^{*}$ \\
\hline
\end{tabular}

Note: ${ }^{*},{ }^{* *}$ and ${ }^{* * *}$ represents level of significance at 1,5 and $10 \%$ respectively. Values of $t$-statistics are in parenthesis.

Table 8 describes the results of the regression analysis when ATO is the dependent variable and the VAIC components are the independent variables. This Table reveals that the adjusted $\mathrm{R} 2$ is $87.8 \%$ which means that the model has good explanatory power. From the results of the Hausman Test it was found that the Fixed Effect Model is more fit to be used. The results exhibit that HCE and company productivity which is represented by ATO have an insignificant and negative relation, meaning that any increase in human capital would have no impact on ATO. Hence, due to present results 
$\mathrm{H}_{2 \mathrm{~b}}$ is rejected and it is concluded that there is no relationship between HCE and productivity of companies. Results also evince that SCE has a positive but no significant impact on ATO. Hence, H3b is not accepted. Table 8 also depicts that CEE has significant role in increasing the productivity of companies at the $1 \%$ significance level which means change in ATO is 0.38 with every 0.1 change in CEE of companies. Therefore, $\mathrm{H}_{4 b}$ is accepted due to the presence of a significant positive relation between CEE and productivity of companies.

Out of control variables, physical capital and size of the companies had a negative but significant association with productivity. Leverage had no relation with productivity. The results also concluded that an increase in physical capital increases the productivity of companies.

Table 8: Panel Regression Results When ATO is Dependent Variable

\begin{tabular}{ccc} 
& Fixed effect & Random effect \\
\hline Intercept & $1.016802^{*}$ & $0.473438^{*}$ \\
HCE & $(3.974)$ & $(5.469)$ \\
& -0.00957 & $0.014561^{* *}$ \\
SCE & $(-1.069)$ & $(2.251)$ \\
& 0.012812 & $-0.2032^{* *}$ \\
CEE & $(0.130)$ & $(-2.446)$ \\
& $0.38772^{*}$ & $0.448262^{*}$ \\
DER & $(9.583)$ & $(14.851)$ \\
& -0.00917 & $-0.01878^{*}$ \\
PC & $(-1.500)$ & $(-3.244)$ \\
& $-0.19183^{* *}$ & $-0.31557^{*}$ \\
SIZE & $(-2.319)$ & $(-4.710)$ \\
& $-0.15695^{* *}$ & 0.028602 \\
Adjusted R & $(-2.049)$ & $(1.388)$ \\
& 0.878 & 0.414 \\
F statistic & $34.739^{*}$ & $42.721^{*}$ \\
& & \\
\hline
\end{tabular}

Note: ${ }^{*},{ }^{* *}$ and ${ }^{* * *}$ represents level of significance at 1,5 and $10 \%$ respectively. Values of t-statistics are in parenthesis. 


\section{IMPLICATIONS}

The present study has several contributions. The empirical analysis gives a framework to analyse IC and its components that have power to influence the performance of companies in a competitive environment. The present study is an extension of IC practices adopted in developed economies to a developing economy and provides their importance in the current globalised scenario. India as a developing nation has a huge potential for intellectual capital. The Government should encourage all companies which are knowledge based by giving tax exemptions and other subsidies. More investment in research and development activities should be encouraged. Proper maintenance and monitoring are required for databases, software and other intellectual property. Government steps for the encouragement of investment in intellectual capital influence the policies made by the government for the general public such as the taxation policy, venture capital, interest rates of intellectual capital projects which, ultimately effects public attitude towards IC and its effect on performance of the firms. The findings of the study have implications for investors, managers as well as practitioners. The study provides that intangible capital has the greatest influence on the performance of the concerned sectors. If a firm does not disclose its intangible resources to outsiders, investors cannot evaluate the efficiency of IC in the creation of value for the firm and therefore, investors price the firm on the basis of disclosed financial and physical capital. This is similar with the results of Firer and Williams (2003) and Gan and Saleh (2008) who found that investors place more importance to physical and financial capital than intellectual capital in South African and Malaysian economies. Therefore, the observed results necessitate the disclosure of all intellectual resources along with financial resources in order to provide a complete picture about their efficiency in generating value. The results of the study can be utilised by managers for the value creation and evaluation purpose. There are various researchers who used secondary data for the measurement of intellectual capital, for such scholars this paper may be a good source of information. 


\section{CONCLUSION}

The present study analysed the performance of intellectual capital efficiency in Indian IT Software companies. Two measures, profitability and productivity were used as a representative of financial performance. The VAIC methodology was adopted for the measurement of intellectual capital. Correlation analysis and Panel regression were used to find how the independent variables relate with the dependent variables. The results of the study depicted that VAIC has a significant and positive impact on profitability of companies indicating that intellectual capital is very helpful in increasing the return on assets of the companies but intellectual capital has no significant impact on a company's productivity.

When ROA was used as the independent variable it was found that human capital has a negative association while structural and physical capital have a significant positive association with a company's profitability. This shows that it is the companies' databases, software, infrastructure and physical capital that assist in increasing the return of companies. Findings of the study can assist managers to maintain and utilize intellectual capital to generate more profits.

When ATO was taken as the independent variable it was found that human capital is not helpful in increasing a company's productivity. Structural capital increases the productivity but not at a significant level. The results also showed that an increase in physical capital increases the company's productivity.

Overall, the study provides that VAIC has greatest significant influence on both measures of performance of concerned sectors and individually all three components of VAIC have a significant impact only on ROA. This shows that none of the VAIC components, except CEE individually, have a positive and significant impact on productivity and market value of the Software firm. These findings imply that investors do not consider intellectual capital efficiency of a firm while investing their money rather, investors price the firm on the basis of disclosed financial and physical capital. Firer and Williams (2003) and Gan and Saleh (2008) also found that investors place more importance to physical and financial capital than intellectual capital in South African and Malaysian economies. Though the 
importance of utilising intellectual capital is growing in the Indian software sector, the reflection of intellectual capital in playing a significant role on financial performance of the software sector is seen to be missing in this analysis. This implies that this conclusion of the study is not limited to the use of IC but applies to physical capital as well. In a nutshell the study concludes that a firm's profitability and productivity can be increased by proper management and maintenance of intellectual capital along with physical capital.

In a nutshell it was found that IC has a varying impact on financial performance of companies. Stakeholders not consider only intellectual while taking decisions, there are many other factors which have a significant influence on company's performance. Other important factors are stakeholder's sentiments and their expectation regarding future prices.

\section{REFERENCES}

Abeysekera, I. (2010). The influence of board size on intellectual capital disclosure by Kenyan listed firms. Journal of Intellectual Capital, 11(4), 504-518.

Ahangar, R. (2011). The relationship between intellectual capital and financial performance: An empirical investigation in an Iranian company. African Journal of Business Management, 5(1), 88-95.

Alipour, M. (2012). The effect of intellectual capital on firm performance: An investigation of Iran insurance companies. Measuring Business Excellence, 16(1), 53-66.

Andriessen, D. (2004). Making sense of intellectual capital: Designing a method for the valuation of intangibles. Oxford: Elsevier ButterworthHeinemann.

Appuhami, B. A. R. (2007). The impact of intellectual capital on investors' capital gains on shares: An empirical investigation of Thai banking, finance and insurance sector. International Management Review, 3(2), $14-25$. 
Bontis, N. (1998). Intellectual capital: An exploratory study that develops measures and models. Management Decisions, 36(2), 63-76.

Bontis, N., Chua, W., \& Richardson, S. (2000). Intellectual capital and the nature of business in Malaysia. Journal of Intellectual Capital, 1(1), 85-100.

Chan, K. H. (2009). Impact of intellectual capital on organisational performance: An empirical study of companies in the Hang Seng Index (Part 1). The Learning Organization, 16(1), 4-21.

Chen, M. C., Cheng, S., \& Hwang, Y. (2005). An empirical investigation of the relation between intellectual capital and firm's market value and financial performance. Journal of Intellectual Capital, 6(2), 159-176.

Chu, S. K. W., Chan, K. H., \& Wu, W. W. Y. (2011). Charting intellectual capital performance of the gateway to China. Journal of Intellectual Capital, 12(2), 249-276.

Cohen, S., \& Kaimenakis, N. (2007). Intellectual capital and corporate performance in knowledge-intensive SMEs. The Learning Organization, 14(3), 241-262.

Edvinsson, L., \& Malone, M. S. (1997). Intellectual capital: Realizing your company's true value by findings its hidden brainpower. New York, NY: Harper Business.

Firer, S., \& Stainbank, L. (2003). Testing the relationship between intellectual capital and a company's performance: Evidence from South Africa. Meditori Accountancy Research, 11, 25-44.

Firer, S., \& Williams, S. M. (2003). Intellectual capital and traditional measure of corporate performance. Journal of Intellectual Capital, 4(3), 348-360.

Gan, K., \& Saleh, Z. (2008). Intellectual capital and corporate performance of technology-intensive companies: Malaysia evidence. Asian Journal of Business and Accounting, 1(1), 113-130. 
Ghosh, D., \& Wu, A. (2007). Intellectual capital and capital markets: Additional evidence. Journal of Intellectual Capital, 8(2), 216-225.

Haanes, K., \& Lowendahl, B. (1997). The unit of activity: Towards an alternative to the theories of the firm. In H. Thomas (Ed.). Strategy, Structure and Style. Copenhagen: Wiley.

Ho, C., \& Williams, S. M. (2003). International comparative analysis of the association between board structure and the efficiency of value added by a firm from its physical capital and intellectual capital resources. The International Journal of Accounting, 38, 465-491.

Horibe, F. (1999). Managing knowledge workers - New skills and attitudes to unlock the intellectual capital in your organisation. Toronto: John Wiley \& Sons.

Hudgins, M. R. (2014). The impact of intellectual capital on the performance of U.S. property-casualty insurance companies. Business and Economics Journal, 5(4), 1-6.

Indian Enterprise Software Market Revenue from 2013 - 2018. Retrieved from https://www.statista.com/statistics/328203/indian-softwaremarket-revenue/

Jashapara, A. (2004). Knowledge management: An integrated approach. Harlow: Pearson Education Limited.

Kaplan, R., \& Norton, D. (1996). The balanced scorecard: Translating strategy into action. Boston: Harvard Business School Press.

Kaur, R., Sharma, K., \& Khanna, Dr. A. (2014). Detecting earning management in India: A sector-wise study. European Journal of Business and Management, 6(11), 11-18.

Kehelwalatenna, S., \& Premaratne, G. (2014). Intellectual capital performance and its long-run behaviour: The US banking industry case. New Zealand Economic Papers, 48(3), 313-333. 
Kehelwalatenna, S. (2016). Intellectual capital performance during financial crises. Measuring Business Excellence, 20(3), 55-78.

Kohli, A. K., \& Jaworski, B. J. (1990). Market orientation: The construct, research propositions, and managerial implications. Journal of Marketing, 54, 1-18.

Komnenic, B., \& Pokrajcic, D. (2012). Intellectual capital and corporate performance of MNCs in Serbia. Journal of Intellectual Capital, 13(1), $106-119$.

Kujansivu, P., \& Lonnqvist, A. (2005). The value and efficiency of intellectual capital in Finnish companies. In 1st Workshop on Visualising, Measuring and Managing Intangibles and Intellectual Capital, Ferrara, Italy, October 18-20, 2005.

Maditinos, D., Chatzoudes, D., Tsairidis, C., \& Theriou, G. (2011). The impact of intellectual capital on firms' market value and financial performance. Journal of Intellectual Capital, 12(1), 132-151.

Maji, S. G., \& Goswami, M. (2015). The journey of IC research: Reflections from the past two decades. Asian Journal of Research in Banking and Finance, 5(6), 85-102.

Mavridis, D. G. (2005). Intellectual capital performance drivers in the Greek banking sector. Management Research News, 28(5), 43-62.

Ministry of Finance (2006). Economic Survey 2005-06. Ministry of Finance, New Delhi, India.

Mondal, D. A. (2016). Application of modified VAIC model for measuring intellectual capital performance. International Journal of Research in Finance and Marketing, 6(11), 19-30.

Nadeem, M., Gan, C., \& Nguyen, C. (2016). Does intellectual capital efficiency improve firm performance in BRICS economies? A dynamic panel estimation. Measuring Business Excellence, 21(1), 65-85. 
Najibullah, S. (2005). An empirical investigation of the relationship between intellectual capital and firms' market value and financial performance in context of Commercial Bank of Bangladesh. Independent University, Bangladesh.

Njuguna, J. I. (2009). Strategic positioning for sustainable competitive advantage: An organizational learning approach. KCA Journal of Business Management, 2(1), 32-43.

Pal, K., \& Soriya, S. (2012). IC performance of Indian pharmaceutical and textile Industry. Journal of Intellectual Capital, 13(1), 120-137.

Patton, J. R. (2007). Metrics for knowledge-based project organizations. Academy of Management Journal, 72(1), 33-43.

Petrash, G (1996). Dow's journey to a knowledge value management culture. European Management Journal, 14(4), 365-373.

Petty, R., \& Guthrie, J. (2000). Intellectual capital literature review Measurement, reporting and management. Journal of Intellectual Capital, 1(2), 155-176.

Pulic, A. (1998). Measuring the performance of intellectual potential in knowledge economy. Retrieved from www.measuring-ip.at/OPapers/ Pulic/Vaictxt/vaictxt.html.

Pulic, A. (2000). VAICe - an accounting tool for IC management. Available at www. measuring-ip.at/Papers/ham99txt.htm.

Rastogi, P. N (2003). The nature and role of IC: Rethinking the process of value creation and sustained enterprise growth. Journal of Intellectual Capital, 4(2), 227-248.

Riahi-Belkaoui, A. (2003). Intellectual capital and firm performance of US multinational firms. Journal of Intellectual Capital, 4(2), 215-226.

Roos, G. (2003). An intellectual capital primer. Cranfield University, Cranfield: Centre for Business Performance. 
Roslender, R., Stevenson, J., \& Kahn, H. (2006). Employee wellness as intellectual capital: An accounting perspective. Journal of Human Resource Costing \& Accounting, 10(1), 48-64.

Sarangi, P. K. (2011). A study on financial performance of software industries with reference to India (Unpublished doctoral thesis). Educational and Research Institute University, Chennai.

Shaban, M., \& Kavida, V. (2013). Intellectual capital, financial performance and market valuation: An empirical investigation of information technology industry in India. Asia-Pacific Journal of Management Research and Innovation, 9(1), 55-62.

Sharabati, A. A., Jawad, S. N., \& Bontis, N. (2010). Intellectual capital and business performance in the pharmaceutical sector of Jordan. Management Decision, 48(1), 105-131.

Singh, I., \& Kaur, N. (2017). Contribution of information technology in growth of Indian economy. International Journal of ResearchGranthaalayah, 5(6), 1-9.

Sofian, S., Tyles, M., \& Pike, R. (2006). The implications of intellectual capital on performance measurement and corporate performance. Jurnal Kemanusiaan, 4(2), 13-24.

Software Sector Analysis Report. (2019). Retrieved November 15, 2019, from equity master website: https://www.equitymaster.com/research-it/ sector-info/software/Software-Sector-Analysis-Report.asp

Stewart, T., \& Ruckdeschel, C. (1998). Intellectual capital: The new wealth of organizations: Wiley Online Library.

Tan, H. P., Plowman, D., \& Hancock, P. (2007). Intellectual capital and financial returns of companies. Journal of Intellectual Capital, 8(1), 76-95.

Ting, I. W. K., \& Lean, H. H. (2009). Intellectual capital performance of financial institutions in Malaysia. Journal of Intellectual Capital, 10(4), 588-599. 
Tseng, C., \& Goo, J. (2005). Intellectual capital and corporate value in an emerging economy: Empirical study of Taiwanese manufacturers. $R \& D$ Management, 35(2), 187-201.

Vishnu, S., \& Gupta, V. (2014). Intellectual capital and firm performance of pharmaceutical firms in India. Journal of Intellectual Capital, 15(1), 83-99.

Wang, W. Y., \& Chang, C. (2005). Intellectual capital and performance in casual models: Evidence from information technology industry in Taiwan. Journal of Intellectual Capital, 6(2), 222-236.

Wernerfelt, B. (1984). A resource-based view of the firm. Strategic Management Journal, 5(2), 171-180.

Williams, S. M. (2000). Is a company's intellectual capital performance and intellectual capital disclosure practices related? Evidence from publicly listed companies from the FTSE 100. 1-41. Available at: www.vaic-on. net/start.htm (accessed 30 June 2019).

Yongvanich, M., \& Guthrie, J. (2005). Extended performance reporting: An examination of the Australian mining industry. Accounting Forum, 29(1), 103-119. 